\title{
Updates on the Species of Shrimps in Kakkaithivu Coastal Waters, Jaffna Estuary, Sri Lanka
}

\author{
S. Piratheepa ${ }^{*}$, K. Chitravadivelu ${ }^{1}$ and U. Edrisinghe ${ }^{2}$ \\ Postgraduate Institute of Agriculture \\ University of Peradeniya \\ Sri Lanka
}

\begin{abstract}
Shrimps are an important commercial fishery resource and highly diverse group in the world. They are considered a luxury food commodity in international trade and command an excellent market price. The marine fishing grounds around Jaffna district and the brackish water resources are more favourable for shrimp production than the other parts of the country. Kakkaithivu Coastal Area is a part of the Jaffna estuary and a major fish landing center in Jaffna peninsula. An investigation was carried out on shrimp species to identify and update the information on shrimp species, in Kakkaithivu Coastal waters, Jaffna district in Northern Province, Sri Lanka. Samples were collected from the commercial catches in Kakkaithivu landing center from November, 2010 through April, 2012.Collected shrimps were initially identified using standard keys according to the morphological features. Seven species of shrimps $\underline{P}$. indicus, $\underline{P}$ monodon, $\underline{P}$. latisulcatus, $\underline{P}$ semisulcatus, $\underline{P}$. japonicus, Metapenaeus monoceros and $\underline{M}$. dobsoni were identified. The presence of $\underline{P}$. japonicus and $\underline{M}$. dobsoni were recorded for the first time in the coastal waters of Kakkaithivu, Jaffna estuary.
\end{abstract}

Keywords: Coastal waters, estuary, shrimp

\section{INTRODUCTION}

Shrimps form the most economically important constituent in the marine fish landings in the world. It is rich in protein and is preferred by majority due to its specific taste. In Sri Lanka, the island blessed with ample brackish water and marine resources.

Jaffna peninsula is situated in the Northern part of Sri Lanka between latitudes $9^{0} \mathrm{~N}$ to $10^{0} \mathrm{~N}$ and longitudes $79^{\circ} \mathrm{E}$ to $80^{\circ} \mathrm{E}$. The fishing grounds around Jaffna district and brackish waters in the district are resourceful compared to fishing grounds in other parts of the country. Jaffna estuary is a shallow coastal water body located on the northern coast of Sri Lanka with vital economic importance. Kakkaithivu Coastal Area is the study area, which is a major fish landing center within Sandillipay Fisheries Inspector Division, Jaffna.

Among the thirty two species of shrimps recorded in Sri Lanka (Jayasinghe, 2001), five species contribute significantly to the commercial catches; namely, $P$. indicus, $P$. monodon, P. meruguiensus, P. semisulcatus and Metapenaeus dobsoni of which the latter dominates the brackish water catches. However, shrimp culture industry, is significantly contributed by

Centre for Development of Fisheries, University of Jaffna, Jaffna, Sri Lanka

Department of Animal Science, University of Peradeniya, Peradeniya, Sri Lanka

Author for correspondence : theepa04@gmail.com 
one species, $P$. monodon. As reported by Chitravadivelu (1993), there were five species of shrimps, namely, P. indicus, P.monodon, P. latisulcatus, P. semisulcatus, and Metapenaeus monoceros had been identified in the Jaffna estuary.

Present study was undertaken with the objective of identifying and updating the shrimp species present in Kakkaithivu Coastal Area, with the aim of contributing for better understanding of the shrimp fishery potential in the area.

\section{MATERIALS AND METHODS}

Study Area: Kakkaithivu Coastal Area was selected for this study. Shrimp species found in this area is considerable and the area is a major fish landing center in Jaffna district (Fig. 1).

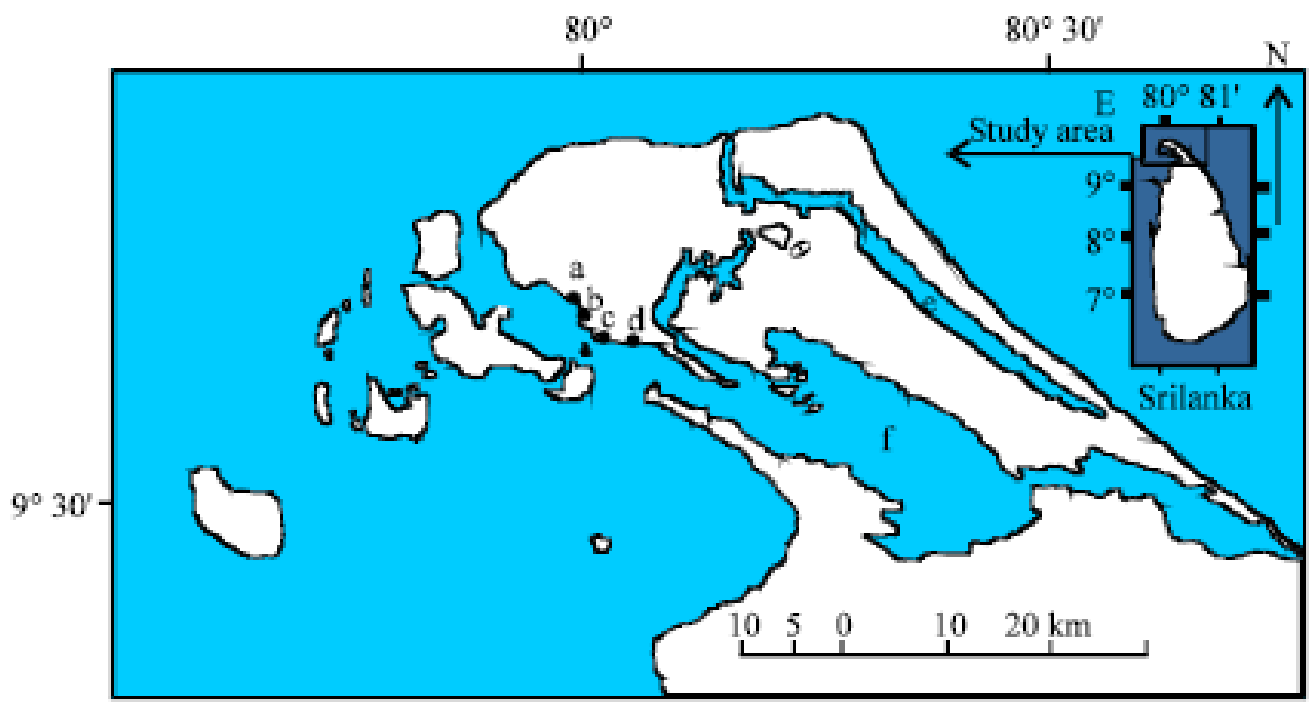

Fig. 1. Location of the Jaffna Estuary

(a) Kakkaithivu, (b) Navanthurai, (c) Kurunagar, (d) Pasaioor (e) Thondaimannar estuary and (f) Jaffna estuary 


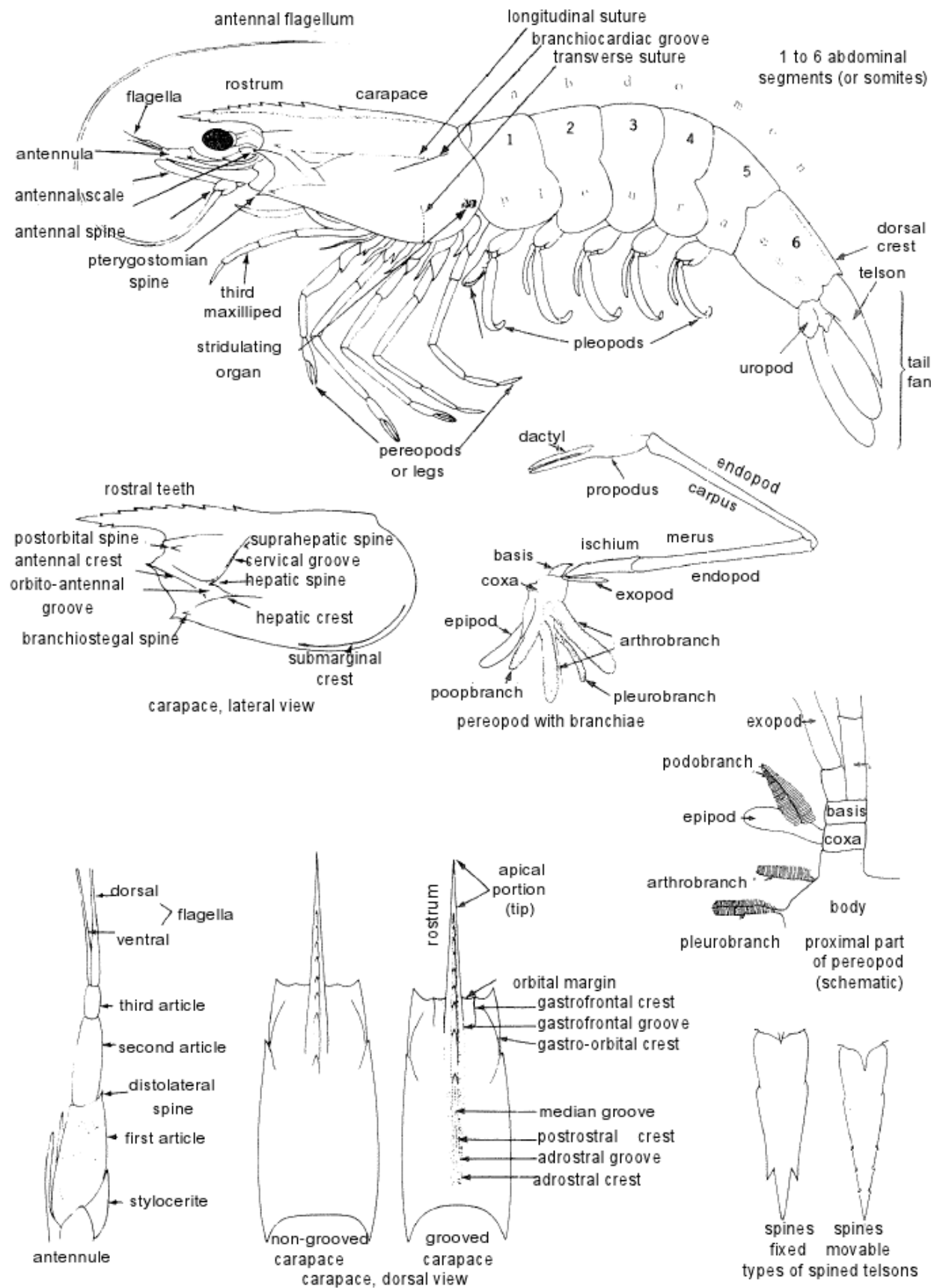

Fig. 2. Schematic representation of the Morphological features used for identification (George and Russell, 1994; Carpenter and Niem, 1998) 
Collection of samples: Random samples of shrimp were collected weekly from the commercial catches in Kakkaithivu Coastal waters from November, 2010 through April, 2012. Data with regard to field collection were recorded.

Sample identification: All the samples were examined under the binocular stereo microscope and hand lens for identification. These shrimps were initially identified using standard keys based on the morphological features (George and Russell, 1994; Carpenter and Niem, 1998). The main features considered were dorsal and ventral rostral teeth, carapace, longitudinal or transverse sutures, cervical and orbito-antennal sulci and antennal carinae, hepatic and antennal spines, basial spines on first and second pereiopods and exopods on the first to fifth pereiopods, subapical spines on telson and adrostral sulcus and carina (Fig. 2).

Identified specimens were preserved in the museum of the Department of Zoology, University of Jaffna.

Table 1. Comparison of morphological characters in the identified species buffer

\begin{tabular}{|c|c|c|c|}
\hline Species & Rostral teeth & $\begin{array}{c}\text { Subapical spines on } \\
\text { telson }\end{array}$ & $\begin{array}{c}\text { Fifth } \\
\text { pereiopods }\end{array}$ \\
\hline $\begin{array}{l}\text { Penaeus indicus } \\
\text { (H.Milne-Edwards, 1837) }\end{array}$ & $\begin{array}{l}\text { Dorsally(7-9) } \\
\text { Ventrally (4-6) }\end{array}$ & no spines (Unarmed) & $\begin{array}{l}\text { With } \\
\text { exopod }\end{array}$ \\
\hline $\begin{array}{l}\text { Penaeus monodon } \\
\text { (Fabricus, 1798) }\end{array}$ & $\begin{array}{l}\text { Dorsally }(7-8) \\
\text { Ventrally }(3-4)\end{array}$ & Unarmed & $\begin{array}{l}\text { Without } \\
\text { exopod }\end{array}$ \\
\hline $\begin{array}{l}\text { Penaeus latisulcatus } \\
\text { (Kishinouye, 1896) }\end{array}$ & $\begin{array}{l}\text { Dorsally }(9-12) \\
\text { Ventrally (1) }\end{array}$ & $\begin{array}{l}\text { Armed with } 3 \text { pairs of } \\
\text { small movable spines. }\end{array}$ & $\begin{array}{l}\text { With } \\
\text { exopod }\end{array}$ \\
\hline $\begin{array}{l}\text { Penaeus semisulcatus } \\
\text { (De Haan,1884) }\end{array}$ & $\begin{array}{l}\text { Dorsally }(5-8) \\
\text { Ventrally }(2-4)\end{array}$ & Unarmed & $\begin{array}{l}\text { With } \\
\text { exopod }\end{array}$ \\
\hline $\begin{array}{l}\text { Penaeus japonicus } \\
\text { (Bate, 1888) }\end{array}$ & $\begin{array}{l}\text { Dorsally (10) } \\
\text { Ventrally (1) }\end{array}$ & $\begin{array}{l}\text { Armed with movable } \\
\text { lateral spines }\end{array}$ & $\begin{array}{l}\text { With } \\
\text { exopod }\end{array}$ \\
\hline $\begin{array}{l}\text { Metapenaeus monoceros } \\
\text { (Miers, 1878) }\end{array}$ & $\begin{array}{l}\text { Dorsally }(9-12) \\
\text { no Ventral teeth }\end{array}$ & $\begin{array}{l}\text { Armed only with } \\
\text { spicules. }\end{array}$ & $\begin{array}{l}\text { Without } \\
\text { exopod. }\end{array}$ \\
\hline $\begin{array}{l}\text { Metapenaeus dobsoni } \\
\text { (Fabricus, 1798) }\end{array}$ & $\begin{array}{l}\text { Dorsally }(7-9) \\
\text { no Ventral teeth }\end{array}$ & $\begin{array}{l}\text { Armed only with } \\
\text { spicules. }\end{array}$ & $\begin{array}{l}\text { Without } \\
\text { exopod }\end{array}$ \\
\hline
\end{tabular}

\section{RESULTS AND DISCUSSION}

Seven shrimp species were identified in the present study. They are Penaeus indicus, Penaeus monodon, Penaeus latisulcatus, Penaeus semisulcatus, Penaeus japonicus, Metapenaeus monoceros and Metapenaeus dobsoni. A comparison of district features of these seven species are summarized in Table 1 and separately illustrated in Plates 3-7.

\section{Penaeus indicus (H. Milne-Edwards, 1837)}

Plate 1 shows the details of P.indicus, which carry white body covered with numerous minute dark brown dots. 


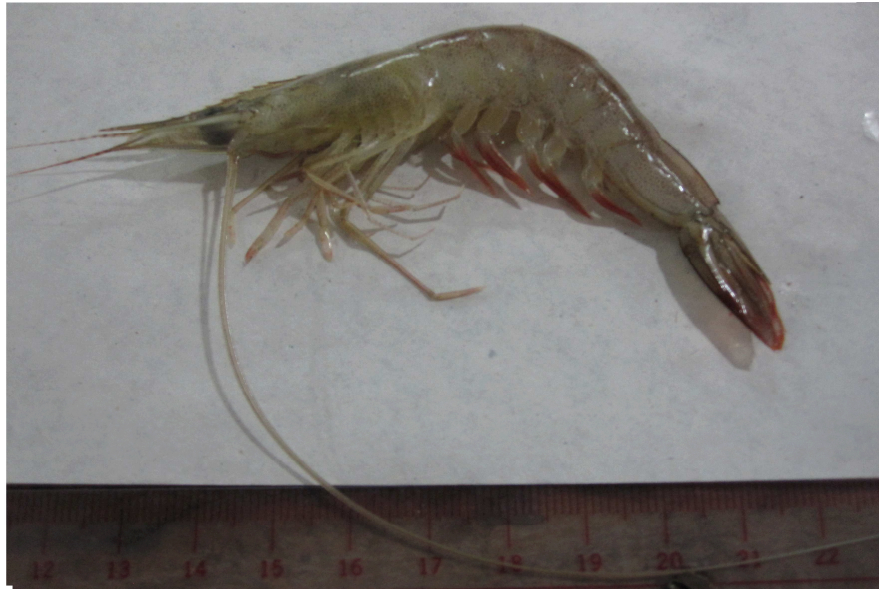

Plate 1. Penaeus indicus

Penaeus monodon (Fabricus, 1798)

A detailed photograph of P. monodon is given in Plate 2. The distinguishable characters of the species include greenish grey body with dark brown bars and pleopods with yellow spot. They carry uniform antenna ranging pink -brown colour.

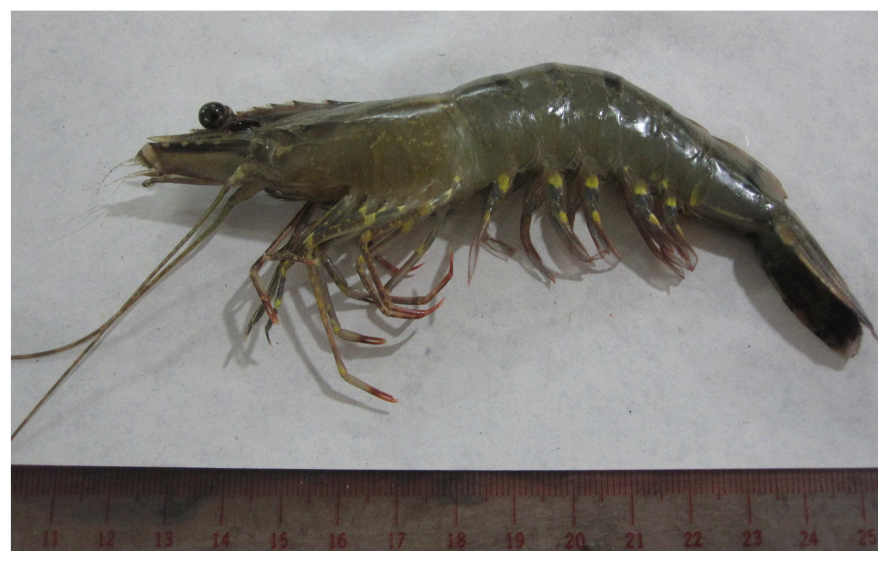

Plate 2. Penaeus monodon

\section{Penaeus latisulcatus ( Kishinouye, 1896)}

Plate 3 depicts the important morphological features of $P$. latisulcatus. The features include pale brown body, short brown stripes in abdomen and yellow pleopods. 


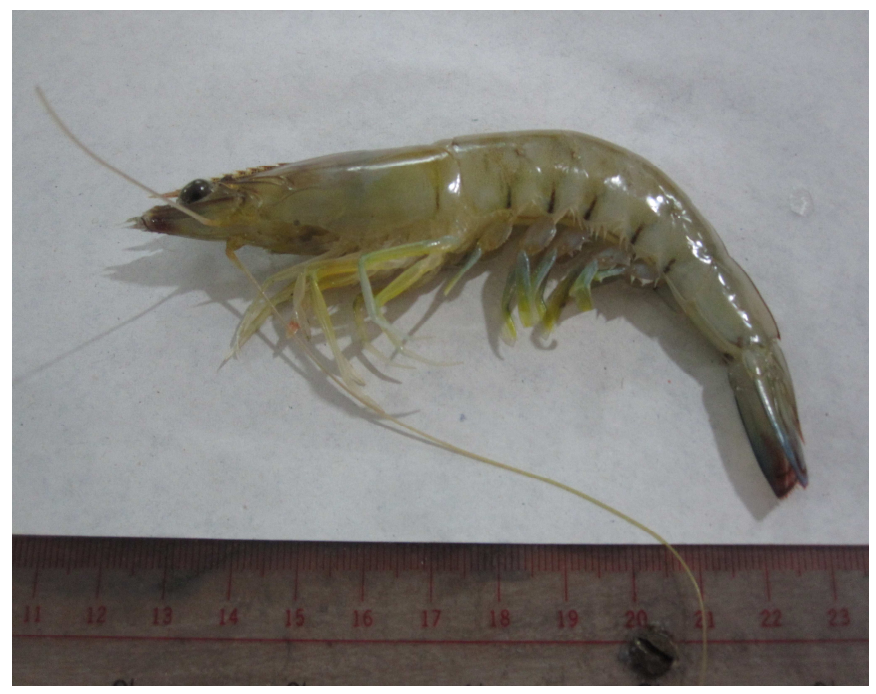

Plate 3. Penaeus latisulcatus.

\section{Penaeus semisulcatus (De Haan, 1884)}

Plate 4 shows the unique features of reddish brown to pale brown body with brownish grey dorsal transverse bands, antenna banded white and brown colours and carapace without longitudinal sutures.

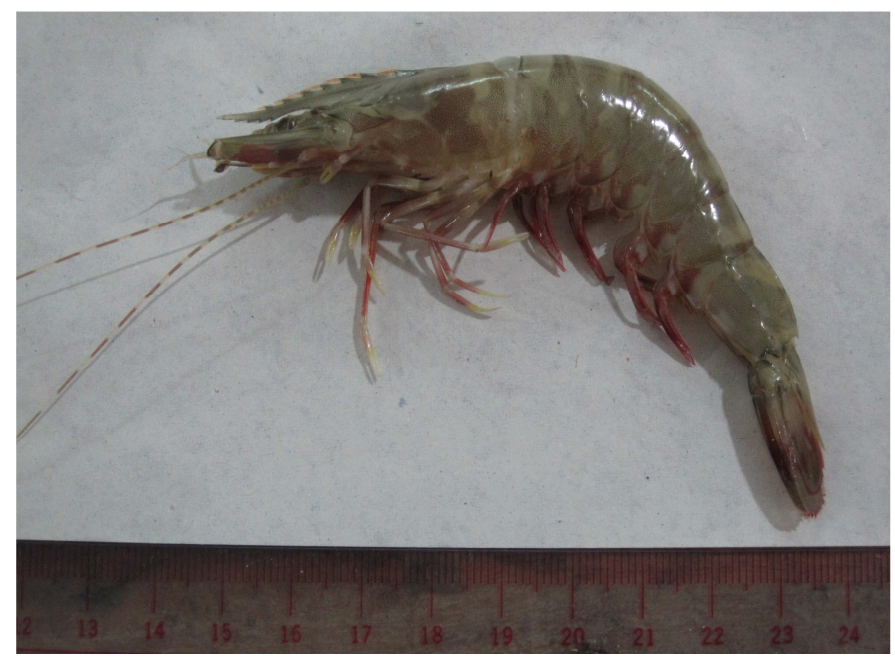

Plate 4. Penaeus semisulcatus

\section{Penaeus japonicus (Bate, 1888)}

Plate 5 shows $P$. japonicus, which carries two bands in carapace. It is clear in the Plate 5 that the last band is not reaching to ventral margin. The body colour is light tan to greenish brown, stripped in clear dark brown stripes. Blue edge at tail fan and yellow legs are very remarkable. 
Piratheepa et al.

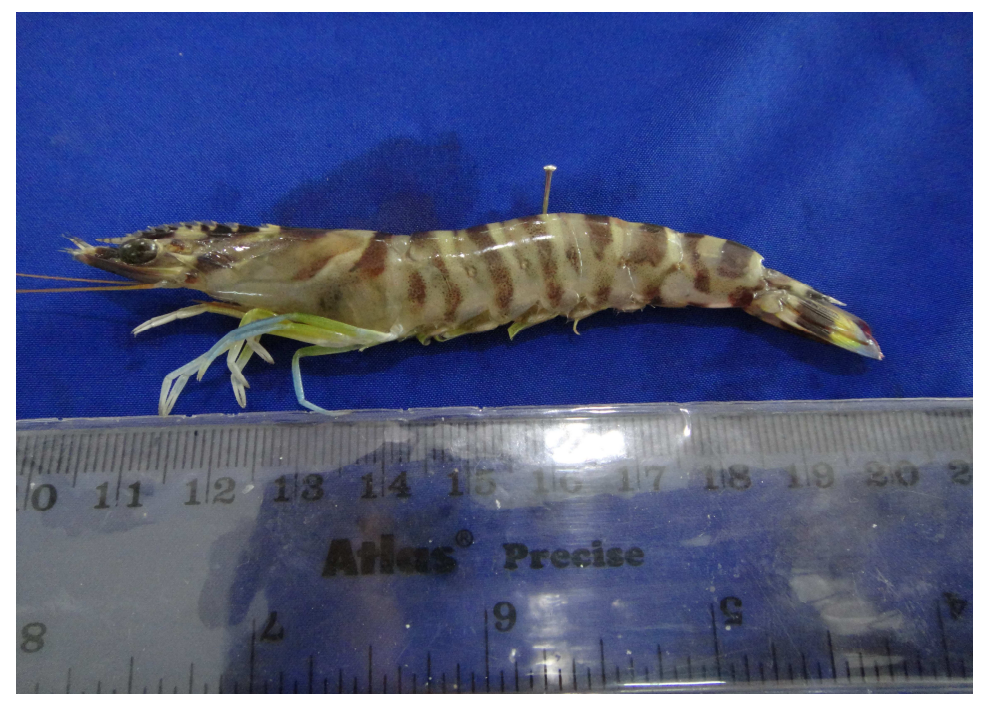

Plate 5. Penaeus japonicus

Metapenaeus monoceros (Miers, 1878)

Plate 6 shows the details of M. monoceros, which carry Greenish grey body.

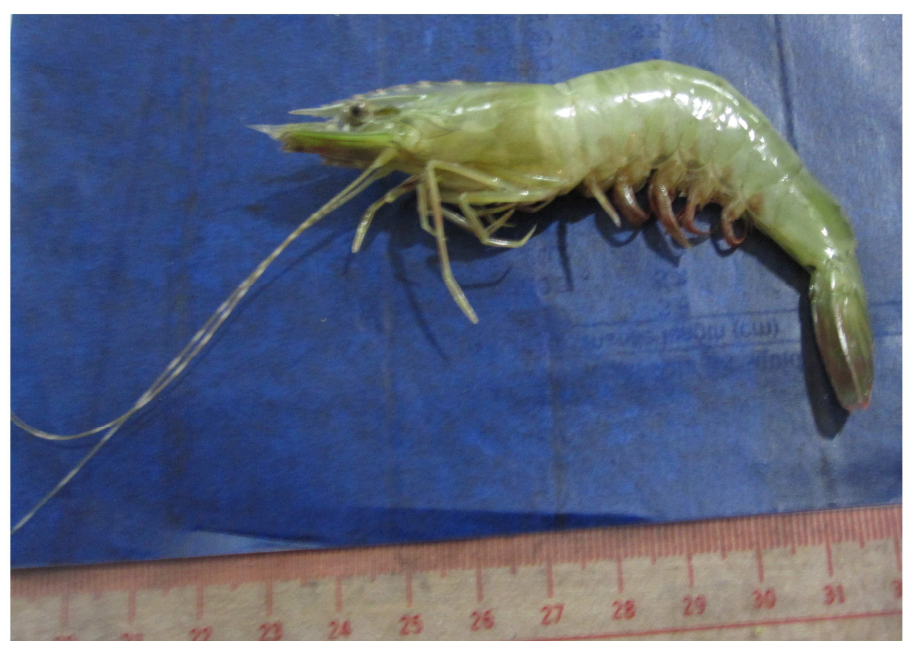

Plate 6. Metapenaeus monoceros

Metapenaeus dobsoni (Fabricus, 1798)

The descriptive feature of $M$. dobsoni is given in Plate 7 which carries pale grayish brown colour body. 


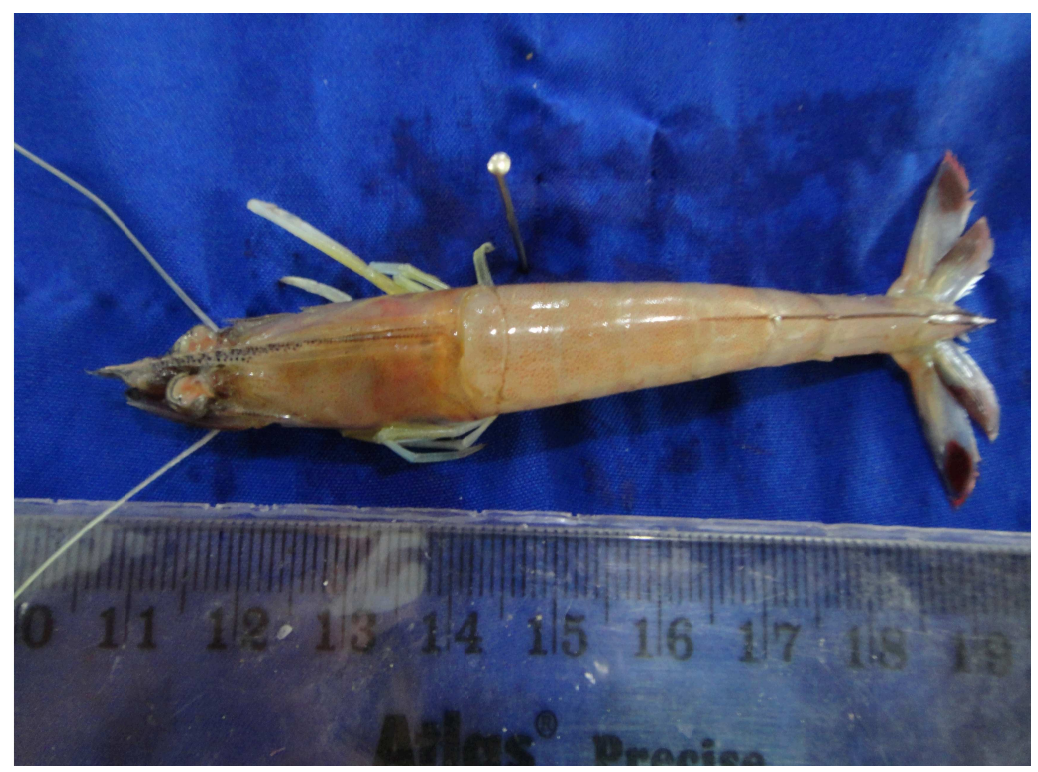

Plate 7. Metapenaeus dobsoni

Seven species (Penaeus indicus, P. monodon, P. latisulcatus, P. semisulcatus, P. japonicus, Metapenaeus monoceros and Metapenaeus dobsoni were found in Kakkaithivu Coastal Area during the present study. Out of the seven species recorded here, five species (Penaeus indicus, P.monodon, P.latisulcatus, P.semisulcatus, and Metapenaeus monoceros) have already been reported by Chitravadivelu and Arudpragasam (1983) in Jaffna estuary. The occurrence of P. japonicus and Metapenaeus dobsoni were recorded for the first time in Kakkaithivu Coastal waters of Jaffna estuary.

Further ecological and biological studies on shrimp are necessary to investigate the factors which influence the pattern of distribution of these species and to implement appropriate conservation strategies to the existing species.

\section{CONCLUSIONS}

At least seven species of shrimps belonging to suborder Penaeoidea exist in Kakkaithivu Coastal Area in Jaffna district in Northern Province. They are identified as Penaeus indicus, P. monodon, P. latisulcatus, P. semisulcatus, P. japonicus, Metapenaeus monoceros and M. dobsoni. Among them P. japonicus and Metapenaeus dobsoni were recorded for the first time in the Jaffna estuary. 


\section{REFERENCES}

Carpenter, K.E. and Niem, V.H. (1998). FAO species identification guide for fishery purposes. The living marine resources of the Western Central Pacific. Cephalopods, crustaceans, holothurians and sharks. Rome, FAO. Volume 2, pp 687-1396.

Chitravadivelu, K and Arudpragasam, K.D. (1983). Studies on the prawn fishery in the Jaffna estuary. Proceeding of Sri Lanka Association for Advancement of Science.39(1), 47

Chitravadivelu, K. (1993). Shrimp culture. University of Jaffna Publication. Mahatma printing works, Eralalai, Jaffna, Sri Lanka. pp 9-14.

George, H.P and Russell, B.C. (1994). FAO species identification field guide for fishery purposes. The marine fishery resources of Sri Lanka, FAO, Rome, Italy, pp 19-37.

Jayasinghe, J.M.P.K. (2001). Background information for preparation of National physical planning policy report No:8. Coastal and Oceanic Resources, Ministry of Fisheries, Colombo, Sri Lanka. pp 1-8. 